\title{
Enhanced thermostability of a Rhizopus chinensis lipase by in vivo recombination in Pichia pastoris
}

Xiao-Wei Yu ${ }^{1,2 \dagger}$, Rui Wang ${ }^{2,3 \dagger}$, Meng Zhang ${ }^{1,2}$, Yan $X u^{1,2^{*}}$ and Rong Xiao ${ }^{1,4}$

\begin{abstract}
Background: Lipase from Rhizopus chinensis is a versatile biocatalyst for various bioconversions and has been expressed at high-level in Pichia pastoris. However, the use of $R$. chinensis lipase in industrial applications is restricted by its low thermostability. Directed evolution has been proven to be a powerful and efficient protein engineering tool for improvement of biocatalysts. The present work describes improvement of the thermostability of $R$. chinensis lipase by directed evolution using P. pastoris as the host.

Results: An efficient, fast and highly simplified method was developed to create a mutant gene library in $P$. pastoris based on in vivo recombination, whose recombination efficiency could reach $2.3 \times 10^{5} / \mu \mathrm{g}$ DNA. The thermostability of r27RCL was improved significantly by two rounds of error-prone PCR and two rounds of DNA shuffling in P. pastoris. The S4-3 variant was found to be the most thermostable lipase, under the conditions tested. Compared with the parent, the optimum temperature of S4-3 was two degrees higher, $T_{m}$ was 22 degrees higher and half-lives at $60^{\circ} \mathrm{C}$ and $65^{\circ} \mathrm{C}$ were 46 - and 23 - times longer. Moreover, the catalytic efficiency $k_{\text {cat }} / K_{\mathrm{m}}$ of $54-3$ was comparable to the parent. Stabilizing mutations probably increased thermostability by increasing the hydrophilicity and polarity of the protein surface and creating hydrophobic contacts inside the protein.

Conclusions: $P$. pastoris was shown to be a valuable cell factory to improve thermostability of enzymes by directed evolution and it also could be used for improving other properties of enzymes. In this study, by using P. pastoris as a host to build mutant pool, we succeeded in obtaining a thermostable variant S4-3 without compromising enzyme activity and making it a highly promising candidate for future applications at high temperatures.
\end{abstract}

Keywords: Lipase, Directed evolution, Thermostability, Mutant library construction, Pichia pastoris

\section{Background}

Lipases (triacylglycerol ester hydrolases EC 3.1.1.3) are enzymes that hydrolyze the ester bonds of waterinsoluble substrates at the interface between substrate and water. They are well known because of their remarkable levels of activity and stability in non-aqueous environments, which makes them as attractive enzyme for use in industrial applications, such as in food, pharmaceutical, chemical and detergent industries [1-3].

Rhizopus lipases have been widely used in food industries $[4,5]$. Nevertheless, most Rhizopus lipases are mesozymes as they are produced by mesophilic organisms

\footnotetext{
* Correspondence: yxu@jiangnan.edu.cn

${ }^{\dagger}$ Equal contributors

'State Key Laboratory of Food Science and Technology, Jiangnan University, 1800 Lihu Avenue, Wuxi 214122, China

${ }^{2}$ Key Laboratory of Industrial Biotechnology, Ministry of Education, School of Biotechnology, Jiangnan University, 1800 Lihu Avenue, Wuxi 214122, China Full list of author information is available at the end of the article
}

and exhibit unfavorable thermostability [6]. For example, lipase RAL from $R$. arrhizus showed poor thermostability when incubated at $30^{\circ} \mathrm{C}$ for $30 \mathrm{~min}$ [7]. Lipase ROL from $R$. oryzae showed highest activity at $35^{\circ} \mathrm{C}$ and about $35 \%$ of the lipase activity was lost after incubation at $45^{\circ}$ $\mathrm{C}$ for $30 \mathrm{~min}$ [8]. Another lipase proROL derived from $R$. oryzae DSM853 exhibited better thermostability with a $T_{\mathrm{m}}$ value of $57.5^{\circ} \mathrm{C}$ [9]. In our previous study, a lipase gene proRCL from $R$. chinensis CCTCC M201021 was cloned and expressed at high-level in Pichia pastoris as r27RCL, whose activity was about 580 times higher than that of wild-type $R$. chinensis lipase [10]. This recombinant enzyme showed a high potential for industrial usage, as an additive for bread baking, synthesis of eicosapentaenoic acid (EPA), docosahexaenoic acid (DHA), sorbitan oleate, and ethyl esters [11-15]. However, the use of lipase r27RCL from $R$. chinensis is restricted by its low thermostability.

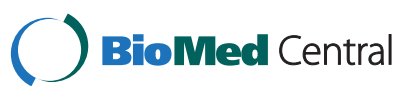


Directed evolution has been proven to be a powerful and efficient protein engineering tool for improvement of biocatalysts [16]. Several lipases from Rhizopus sp. were subjected to directed evolution in an effort to produce thermostable variants $[7,17]$. The half-life of RAL expressed in $P$. pastoris was prolonged by 12 -fold at $50^{\circ} \mathrm{C}$ [7]. The $T_{\mathrm{m}}$ value of $\mathrm{RNL}$ from $R$. niveus expressed in Saccharomyces cerevisiae was improved from $47^{\circ} \mathrm{C}$ to $57^{\circ} \mathrm{C}$ [17].

The production of an active Rhizopus lipase has been performed in Escherichia coli [18], S. cerevisiae [19] and $P$. pastoris [20-22], among which the expression of Rhizopus lipase in $P$. pastoris was the best. The $P$. pastoris expression system offers several advantages, as a desirable host in directed evolution, for easy library screening and further industrial application, such as the ability to perform eukaryotic protein modifications, high levels of protein expression at the intra- or extracellular level and an alcohol oxidase 1 ( $A O X 1)$ gene promoter tightly regulated by methanol $[23,24]$. However, mutant library construction in $P$. pastoris usually requires time-consuming multistep procedures which include an intermediate bacterial host (E. coli) and restriction digestion procedures [25].

In this work, we developed a faster and simplified mutant library production method, based on which, the thermostability of the lipase r27RCL from $R$. chinensis CCTCC M201021 was improved by directed evolution.

\section{Results and discussion Library construction}

A novel approach for lipase mutant library construction in P. pastoris was established based on the formation of a recombination cassette in vivo (Figure 1). Three pairs of overlapping primers were used to generate the mutant gene (fragment $\mathrm{B} / \mathrm{C}$ ) and two different vector fragments (A and D). Primer BC-F had 66 bp overlapped pairs with the 5 '-end of the gene sequence ("a" in Figure 1) of fragment $\mathrm{D}$ and primer BC-R had $60 \mathrm{bp}$ overlapped pairs with the 3 '-end of the gene sequence (" $b$ " in Figure 1) of fragment $\mathrm{A}$. Therefore, fragment $\mathrm{B} / \mathrm{C}$ generated by primers BC-F and BC-R had $66 \mathrm{bp}$ and $60 \mathrm{bp}$ overlapped sequences with vector fragments $D$ and $A$. The lipase gene fragment $\mathrm{B}$ (or $\mathrm{C}$ ) and vector fragments $\mathrm{A}$ and $\mathrm{D}$ were mixed and transformed into $P$. pastoris competent cells by electroporation. In vivo, the fragments $\mathrm{A}, \mathrm{B} / \mathrm{C}$ and $D$ self-reassembled to form a recombination cassette relying on the $60 \mathrm{bp}$ and $66 \mathrm{bp}$ homologous arms between them (Steps 1 and 2 in Figure 1). The selfreassembled expression cassette was integrated into the genome of $P$. pastoris by homologous recombination of the flanking $A O X 1$ gene sequences (Steps 3 and 4 in Figure 1).
Recombination efficiency is one of the most important factors in directed evolution. In order to improve the recombination efficiency, the effects of the fragment molar ratio and the length of the overlapping sequences for recombination were investigated. As shown in Table 1, the recombination efficiency was improved with the increased molar ratio of fragment B/C:A:D in the DNA mixture by electroporation. About $2.3 \times 10^{5} / \mu \mathrm{g}$ DNA recombinants were obtained when the molar ratio reached 10:1:1 and the values dropped to $1.8 \times 10^{5} / \mu \mathrm{g}$ DNA, $1.2 \times 10^{5} / \mu \mathrm{g}$ DNA or $1.0 \times 10^{5} / \mu \mathrm{g}$ DNA when the molar ratio was $5: 1: 1,3: 1: 1$ or $1: 1: 1$. In order to obtain high recombination efficiency, the fragment molar ratio B/C:A:D of 10:1:1 was chosen. The recombination efficiency was low with shorter overlapping sequences $(<55 \mathrm{bp})$ due to the difficulty in formation of a recombination cassette in vivo, while too long overlapping sequences $(>70 \mathrm{bp}$ ) resulted in PCR technical difficulties with blurred and weak target bands when amplified with such long primers. Medium length of overlapping sequences $(55-70 \mathrm{bp})$ generated satisfied recombination efficiency without PCR technical difficulties (Table 1). It is well known that homologous recombination is a common characteristic of yeast. Baudin et al. [26] demonstrated that the amount of homology necessary to promote efficient recombination-mediated gene disruption in S. cerevisiae is in the order of 30-50 bp. Oldenburg et al. [27] reported that $20 \mathrm{bp}$ of homology is sufficient to generate the PCR-directed recombination in $S$. cerevisiae, at least under certain conditions (vector: insert 1:6).

In this work, in order to make directed evolution practical in the host organism $P$. pastoris an efficient, fast and highly simplified method was developed to create a gene mutant library in $P$. pastoris. This method went a crucial step beyond previous approaches [25,28-30] because it completely discarded time-consuming multistep procedures including construction of recombinant plasmid, transformation of an intermediate bacterial host (E. coli), plasmid isolation and linearization. In our approach, only three PCR amplification processes and an electroporation step were required. Fernandez et al. [31] also reported a method to produce a mutant library in $P$. pastoris, which reassembled a recombination cassette in vitro and produced about 6000 colonies per $1 \mu \mathrm{g}$ of linear DNA. The method developed in our research was more convenient and efficient since selfreassembly of the linear recombinant cassette occurred in vivo.

\section{Thermostable variants}

The thermostability of r27RCL was improved by combining two rounds of error-prone PCR and two rounds of DNA shuffling (Figure 2). Error-prone PCR was used 

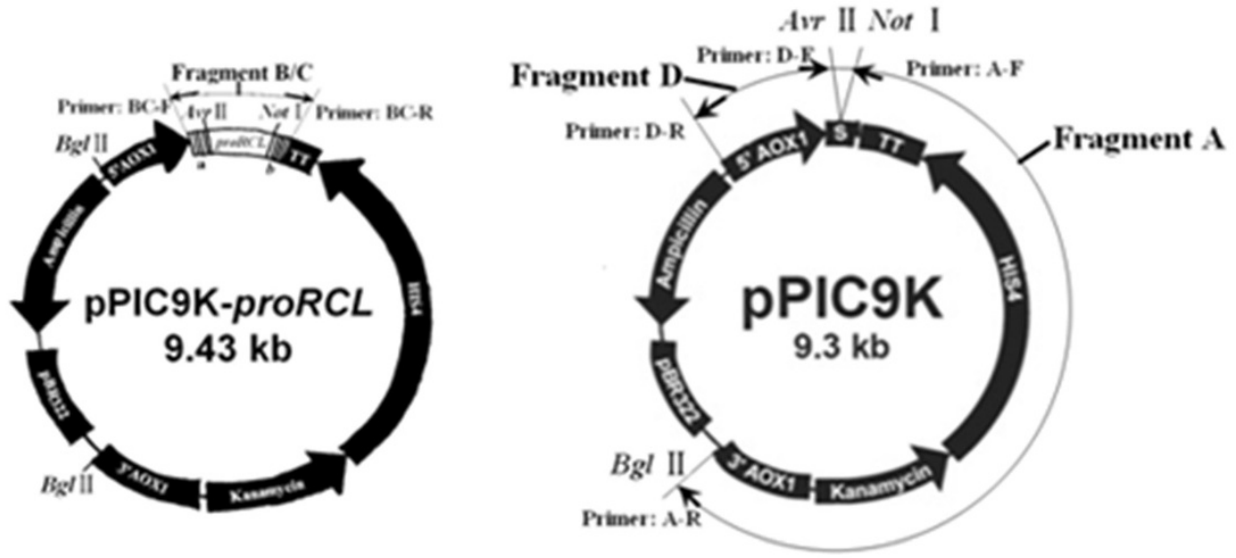

ep-PCR or DNA Shuming

Fragment $B / C$
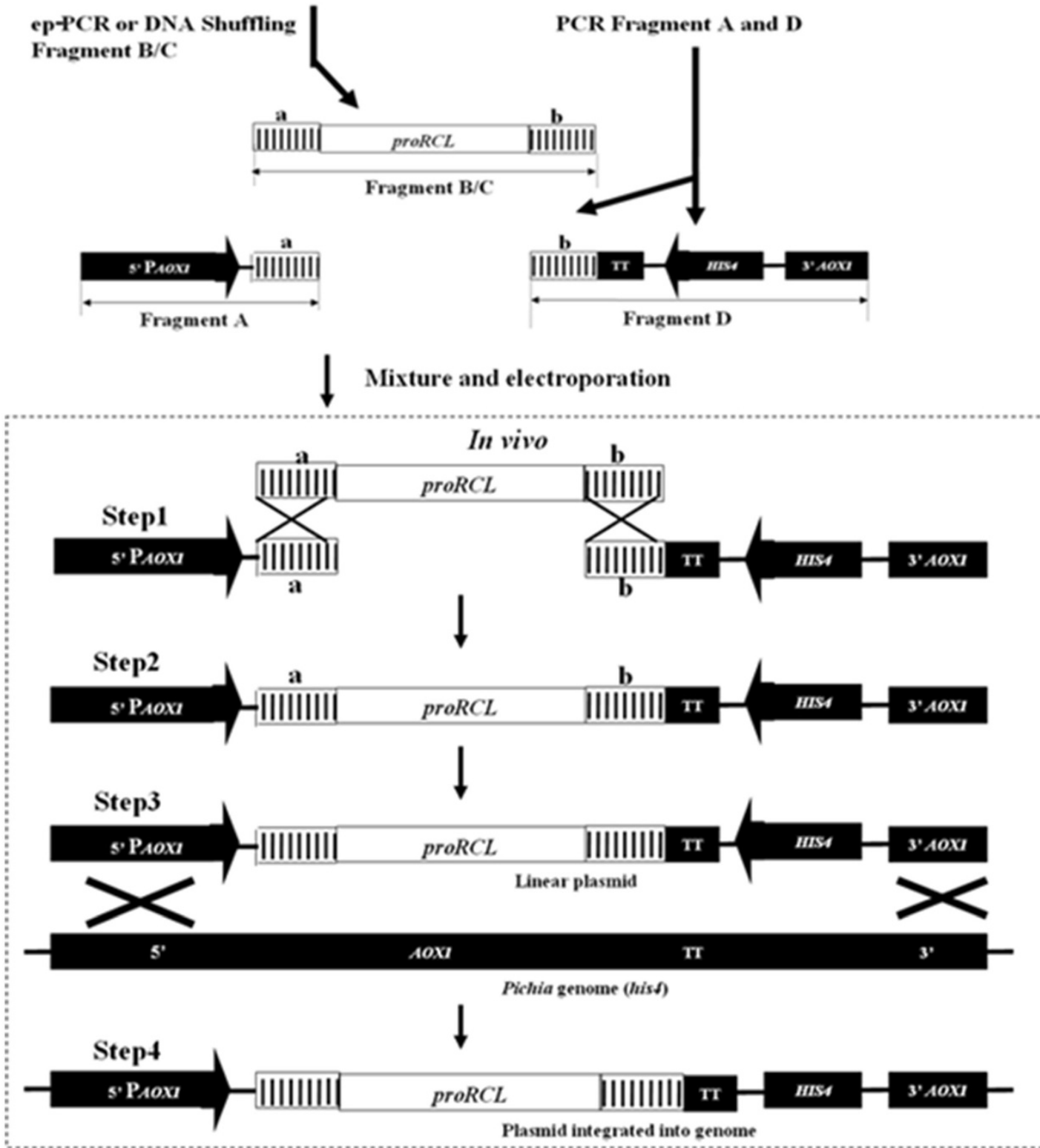
(See figure on previous page.)

Figure 1 The novel approach of construction of the lipase mutant library in $P$. pastoris based on the formation of a recombination cassette in vivo. The hatched areas (a) and (b) were overlapped sequences between amplified fragments

to introduce an average of 1 to 2 amino acid substitutions per proRCL gene and DNA shuffling could combine beneficial mutations as well as create new mutations. After creating the first-generation mutant library using error-prone PCR, approximately 5000 clones were screened for increased thermostability at $45^{\circ} \mathrm{C}$. Two variants (ep1-1 and ep1-26) were identified and confirmed to have longer half-lives at $60^{\circ} \mathrm{C}$ (Table 2). ep1-1 (P168L, V329A) and ep1-26 (S234F) with a total of three substitutions were chosen as templates for generating the second-generation mutant library using error-prone PCR. Only $0.1 \%$ of the second generation mutant pool (5200 clones) screened at $50^{\circ} \mathrm{C}$ exhibited better performance than the first-generation parents. The identified variants ep2-3, ep2-4, ep2-8 and ep2-12 were selected for DNA shuffling. It was interesting to note that ep2-8 (S234F, P168L, K219D) and ep2-12 (S234F, V329A, K161R) both acquired mutations that were derived from ep1-1 and ep1-26 via in vivo DNA shuffling. From each generation of DNA shuffling, approximately 10000 clones were screened for increased thermostability. The third-generation evolution produced three variants (S3-1, S3-4, S3-18) whose thermostability slightly increased, whereas the last generation of evolution yielded three variants (S4-3, S4-13, S4-20) with significantly improved thermostability (Figure 2). S4-3 was the most thermostable variant. It contained five mutations (A129S, A230T, S234F, L180H, H317P) observed in previous generations plus one new mutation (T218S) generated by the fourth round of DNA shuffling.

\section{Thermostabilities of the evolved lipases}

Table 2 lists the $t_{1 / 2}$ values of the parent and the evolved thermostable variants during four generations of directed evolution. At $60^{\circ} \mathrm{C}$ the $t_{1 / 2}$ of the parent was $4 \mathrm{~min}$. The variants from the first and the second generations had half-lives of thermal inactivation two- to five-fold longer than the parent. The half-lives of the three variants discovered from the third round of directed evolution (DNA shuffling) were 10 to 14 times longer than that of the parent at $60^{\circ} \mathrm{C}$. The last round of mutagenesis resulted in three variants that had the longest half-lives of thermal inactivation, 40 to 46 times longer than the parent at $60^{\circ} \mathrm{C}$, among which, S4-3 was the most thermostable enzyme. The enzymatic properties of the purified S4-3 were then studied and its thermomechanism was explored.
Initial activity vs thermostability of variants

In order to determine the relationship between thermostability and enzyme activity, the initial activities of all 12 variants were measured. As shown in Figure 3, five variants exhibited improved $T_{\mathrm{m}}$ as well as higher activity. The activities of the other 7 variants were not affected much by increased thermostability, among which S3-1, with the lowest activity, still retained about $90 \%$ activity compared to the parent enzyme. These results provided strong evidence that improvement of thermostability and maintenance of enzyme activity could be simultaneously achieved, and improved thermostability did not occur at the expense of activity at low temperatures [32-34].

\section{Enzymatic properties of the thermostable variant S4-3}

The most thermostable variant in the last generation, S4-3, was purified and its enzymatic properties were investigated. As shown in Figure 4, the residual activities of S4-3 and the parent were determined after incubation at different temperatures for $30 \mathrm{~min}$. S4-3 displayed greatly- increased thermostability in the range of $20^{\circ} \mathrm{C}$ $-60^{\circ} \mathrm{C}$ and retained $50 \%$ residual activity at $67^{\circ} \mathrm{C}$, whereas the parent started to denature at $40^{\circ} \mathrm{C}$ and was completely inactivated at $60^{\circ} \mathrm{C}$ after $30 \mathrm{~min}$ heat-treatment.

The thermal inactivation of S4-3 and the parent were characterized by incubation at $60^{\circ} \mathrm{C}$ and $65^{\circ} \mathrm{C}$ (Figure 5). The thermal inactivation curves of the parent at $60^{\circ} \mathrm{C}$ and $65^{\circ} \mathrm{C}$ were much steeper than those of S4-3, and the

\section{Table 1 The effects of the fragment molar ratio of B/C:A: $D$ and the length of the overlapping sequences on} recombination efficiency

\begin{tabular}{|c|c|c|}
\hline Method & & $\begin{array}{l}\text { Recombination } \\
\text { efficiency }{ }^{c}\left(\times 10^{5},\right. \\
\text { recombinants } / \mu \mathrm{g} \text { DNA })\end{array}$ \\
\hline \multirow{4}{*}{$\begin{array}{l}\text { Fragment } B / C: A: D \\
\text { (molar ratio) }^{a}\end{array}$} & $10: 1: 1$ & 2.30 \\
\hline & $5: 1: 1$ & 1.80 \\
\hline & $3: 1: 1$ & 1.20 \\
\hline & $1: 1: 1$ & 1.05 \\
\hline \multirow{6}{*}{$\begin{array}{l}\text { Length of overlapping } \\
\text { sequences }(b p) b\end{array}$} & 10 & 0.10 \\
\hline & 25 & 0.80 \\
\hline & 40 & 1.25 \\
\hline & 55 & 1.75 \\
\hline & 70 & 2.32 \\
\hline & 85 & 2.35 \\
\hline
\end{tabular}

\footnotetext{
a The length of overlapping sequence was kept at $65 \mathrm{bp}$.

${ }^{b}$ The fragment molar ratio of B/C:A:D was kept at 10:1:1.

c Recombination efficiency is the number of recombinant cells (recombinants) generated by $1 \mu \mathrm{g}$ of DNA fragments in a transformation procedure.
} 


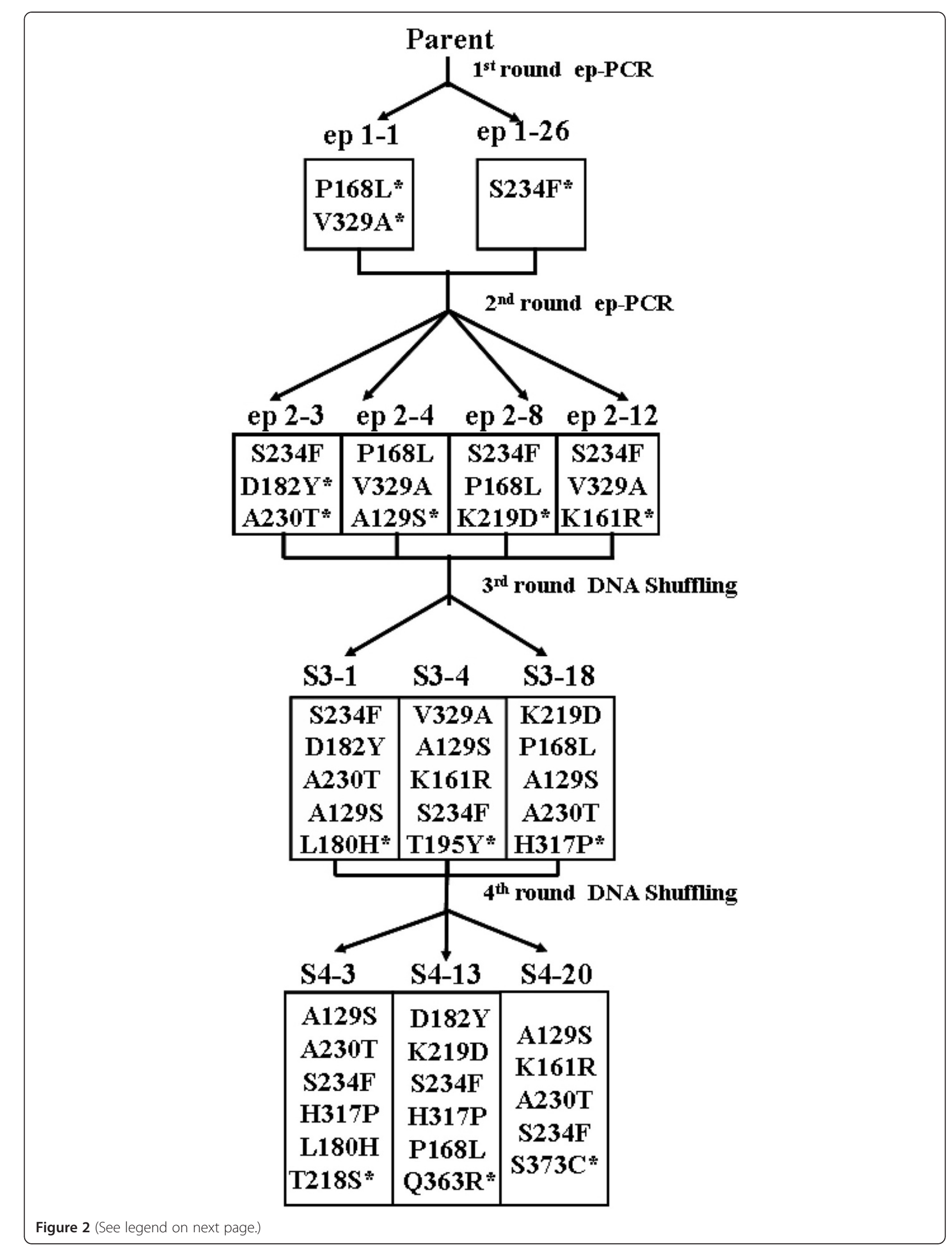


half-lives of S4-3 at $60^{\circ} \mathrm{C}$ and $65^{\circ} \mathrm{C}$ were 23 - and 46 -fold higher than those of the parent. In addition, the optimum temperature of S4-3 was also increased by $2^{\circ} \mathrm{C}$ compared with that of the parent (data not shown).

Kinetic parameters of the parent and S4-3 towards $p$ NPP were calculated and listed in Table 3. S4-3 exhibited a $32 \%$ decrease in $K_{\mathrm{m}}$ whereas a $33 \%$ increase in $k_{\text {cat }}$, resulted in almost identical catalytic efficiency $k_{\text {cat }} / K_{\mathrm{m}}$ compared to the parent.

\section{Thermo-mechanism of S4-3}

The three-dimensional homology model of r27RCL shows that the five mutations A129S, A230T, S234F, $\mathrm{L} 180 \mathrm{H}, \mathrm{T} 218 \mathrm{~S}$ were all present on the surface of the enzyme and far from the catalytic domain (S265-D324H377) except for the mutation H317P (Figure 6). It is consistent with the notion that the initial steps in protein unfolding during the irreversible thermal denaturation primarily involve surface-located parts of the protein $[35,36]$.

The contributions of mutations A230T and A129S toward thermostability could be interpreted based on the structure model which located them at the end of $\alpha$-helix and in a loop on the protein surface. The substitution of A230 for T230 and A129 for S129 may have increased the hydrophilicity and polarity of the protein, which enhanced the thermostability of the enzyme [37]. Mutation L180H located in a loop on the protein surface introduced a positively-charged residue which may increase protein stability by creating a more favorable surface charge

Table 2 Thermostability of enzyme variants from each generation

\begin{tabular}{|c|c|c|c|}
\hline Generation & Variant & $t_{1 / 2}\left(\min\right.$, at $\left.60^{\circ} \mathrm{C}\right)$ & Fold Improvement \\
\hline 0 & parent & 4.0 & 1.0 \\
\hline \multirow[t]{2}{*}{1} & ep 1-1 & 9.8 & 2.4 \\
\hline & ep 1-26 & 8.7 & 2.2 \\
\hline \multirow[t]{4}{*}{2} & ep 2-3 & 11.3 & 2.8 \\
\hline & ep 2-4 & 21.7 & 5.4 \\
\hline & ep 2-8 & 14.4 & 3.6 \\
\hline & ep 2-12 & 13.5 & 3.4 \\
\hline \multirow[t]{3}{*}{3} & S 3-1 & 38.8 & 9.7 \\
\hline & S 3-4 & 58.9 & 13.9 \\
\hline & S 3-18 & 48.0 & 12.0 \\
\hline \multirow[t]{3}{*}{4} & $54-3$ & 184.0 & 46.0 \\
\hline & $54-13$ & 168.3 & 42.1 \\
\hline & S 4-20 & 159.5 & 40.0 \\
\hline
\end{tabular}

distribution [38,39], as found in engineered thermostable cold shock proteins [40]. The mutation S234F was located in an $\alpha$-helix on the protein surface. It was surprising that replacement of an uncharged hydrophilic residue for a nonpolar hydrophobic residue (S234F) at the protein surface increased protein stability but this effect has been observed previously [40,41]. The H317P mutation is buried inside the protein in a $\beta$-strand. There are two assumptions that could be made to explain the improved thermostability. The first assumption was the addition of a hydrophobic residue. In the stabilized variant S4-3, hydrophilic histidine was replaced by hydrophobic proline, whose side-chain engaged in hydrophobic contacts with the side chain of Y293. This interaction was further improved by surrounding hydrophobic amino acids such as L137 and V341 and therefore enhanced protein stability. The alternative explanation was a reduction of the entropy of unfolding. The proline residue, with its pyrrolidine ring, had the lowest conformational entropy, thus the mutation histidine to proline should decrease the entropy of protein in the unfolded state and stabilize the protein [37].

It must be noted that the above-assumed thermomechanisms of S4-3 have been observed in many evolved thermostable enzymes and naturally-occuring thermophilic and hyperthermophilic proteins [35,42]. Determination of the crystal structure of S4-3 should

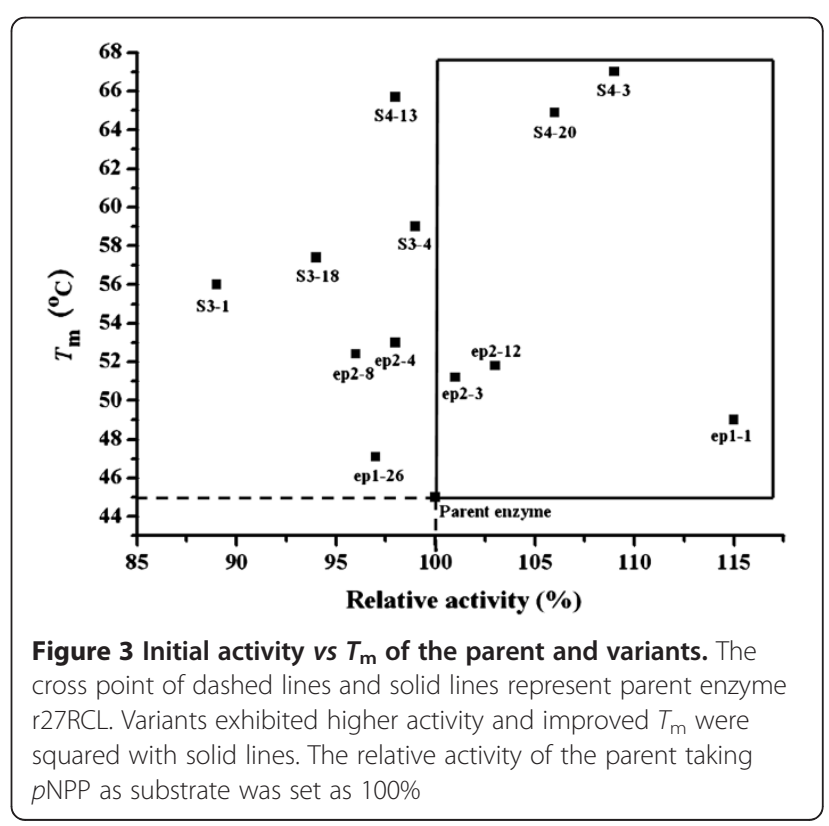




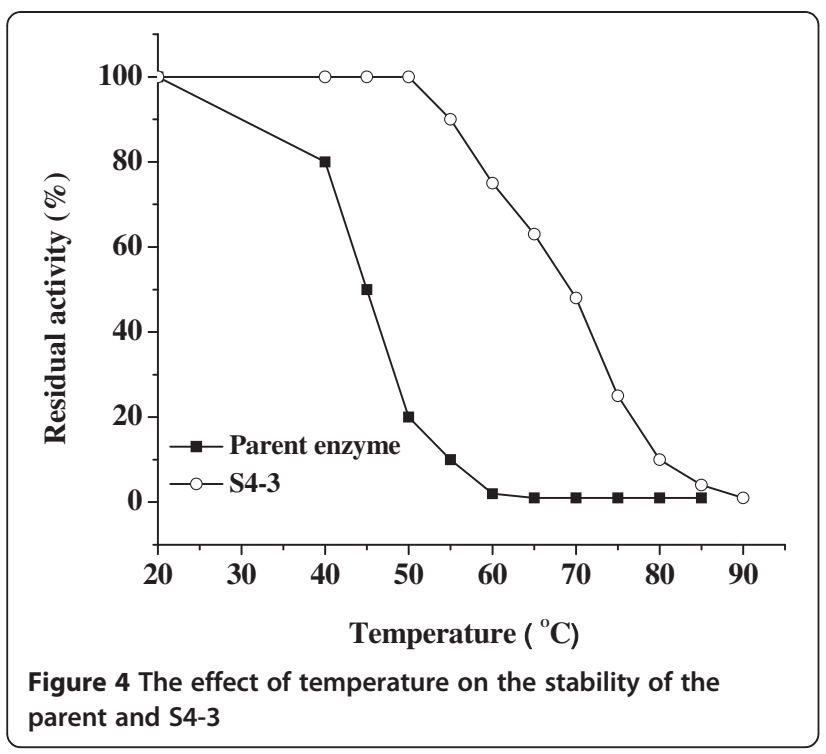

further confirm its thermo-mechanism. But, the crystal structure of r27RCL has not been reported before. Even if it is available, it is still difficult to predict the specific thermostabilizing mutations based on its structure because there are so many structural features that stabilize proteins [37] and the contribution of each feature to the total free energy of thermostability is quite small.

\section{Conclusion}

$P$. pastoris proved to be a valuable cell factory for the directed evolution of the lipase from $R$. chinensis for thermostability improvement, especially when combined with the novel method of library construction described
Table 3 Kinetic parameters of the parent and S4-3

\begin{tabular}{cccc}
\hline Enzyme & $\boldsymbol{K}_{\mathbf{m}}(\mathbf{m m o l} / \mathbf{m i n} / \mathbf{m g})$ & $\boldsymbol{k}_{\text {cat }}\left(\mathbf{s}^{-1}\right)$ & $\boldsymbol{k}_{\text {cat }} / \boldsymbol{K}_{\mathbf{m}}\left(\mathbf{M}^{-1} \mathbf{s}^{-1}\right)$ \\
\hline r27RCL & 0.304 & 18.9 & $6.22 \times 10^{4}$ \\
\hline S4-3 & 0.402 & 25.1 & $6.24 \times 10^{4}$ \\
\hline
\end{tabular}

here. In the present study, the thermostability of r27RCL was improved significantly by two rounds of error-prone PCR and two rounds of DNA shuffling in P. pastoris. The S4-3 variant is the most thermostable lipase from Rhizopus sp., under the conditions tested. Compared with the parent $\mathrm{r} 27 \mathrm{RCL}$, the optimum temperature of S4-3 was two degrees higher, $T_{\mathrm{m}}$ was 22 degrees higher and half-lives at $60^{\circ} \mathrm{C}$ and $65^{\circ} \mathrm{C}$ were 46 - and 23 - times longer, respectively. Moreover, the catalytic efficiency $k_{\mathrm{cat}} / K_{\mathrm{m}}$ of S4-3 was comparable to the parent. In summary, S4-3 maintained good catalytic properties and exhibited much greater tolerability and stability at high temperatures, which made this variant a promising candidate for industrial applications at high temperatures.

\section{Methods}

Strains, plasmid, reagents and cultures

Restriction endonucleases, Taq DNA polymerase were purchased from Takara. All chemicals were of analytical grade or higher quality and purchased from Sigma. $P$. pastoris GS115 ( $\mathrm{His}^{-} \mathrm{Mut}^{+}$) and the pPIC9K expression vector are from Invitrogen BV. Recombinant plasmid pPIC9K-proRCL and strain GS115/ pPIC9K-proRCL were constructed by $\mathrm{Yu}$ et al. [10]. The media used in this study include YPD $(10 \mathrm{~g} / \mathrm{L}$ yeast extract, $20 \mathrm{~g} / \mathrm{L}$ peptone, 20g/L dextrose), MD (13.4g/L YNB, $0.016 \mu \mathrm{M}$

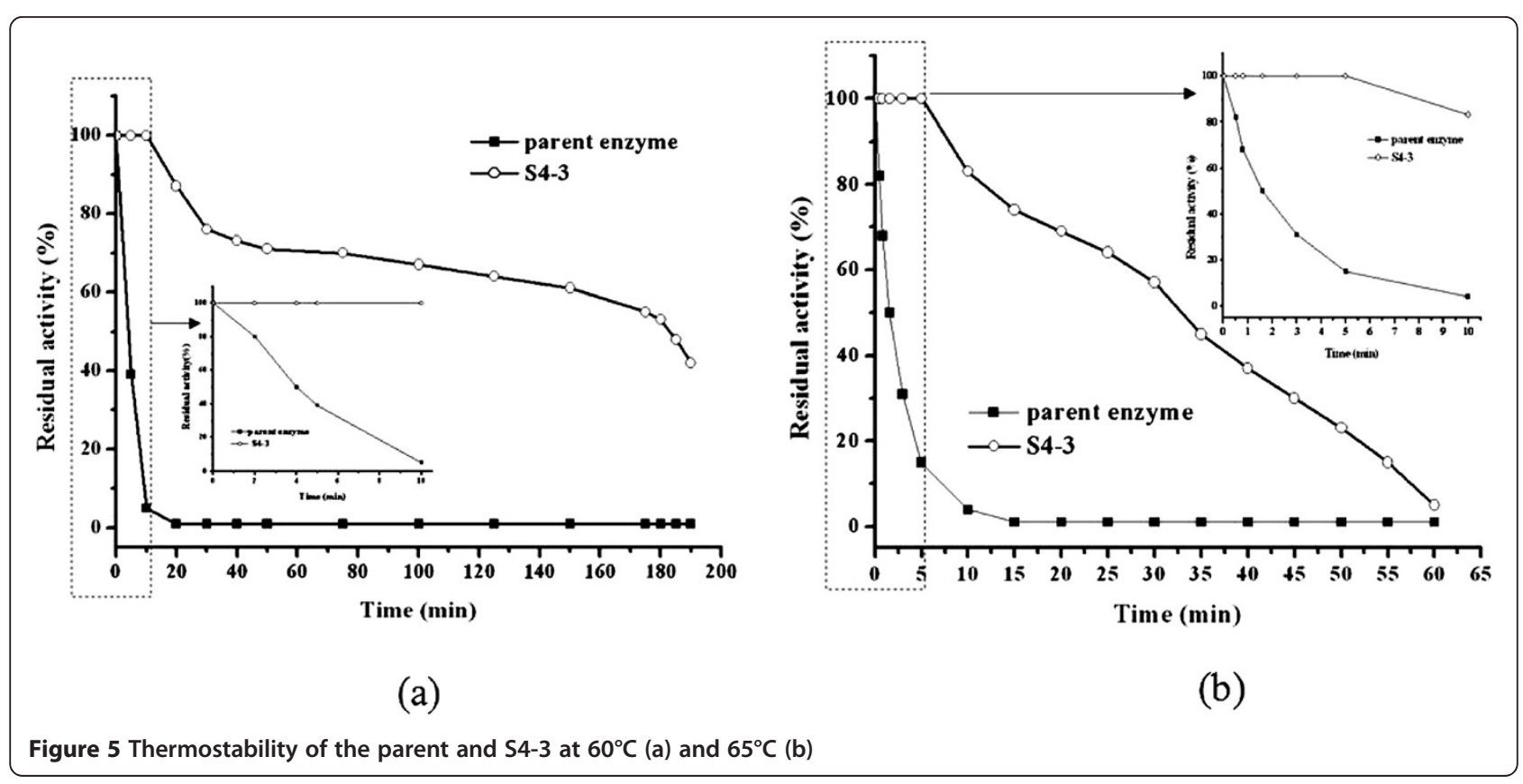




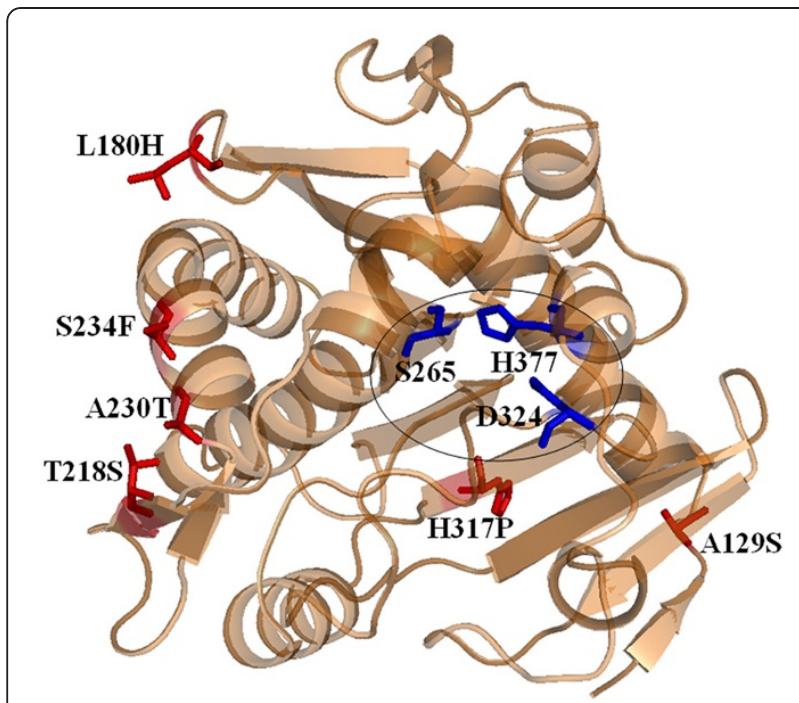

Figure 6 Three-dimensional structure of r27RCL. Locations of six amino acid substitutions (A129S, A230T, S234F, L180H, T218S, H317P) in S4-3 were shown in red sticks and the catalytic residues were shown in blue sticks (in the oval)

biotin, 20g/L dextrose), BMGY (10g/L yeast extract, 20g/L peptone, 10g/L glycerol, pH $6.0100 \mathrm{mM}$ potassium phosphate, 13.4g/L YNB, $0.016 \mu \mathrm{M}$ biotin), BMMY $(10 \mathrm{~g} / \mathrm{L}$ yeast extract, $20 \mathrm{~g} / \mathrm{L}$ peptone, $10 \mathrm{~g} / \mathrm{L}$ methanol, $\mathrm{pH}$ 6.0 $100 \mathrm{mM}$ potassium phosphate, 13.4g/L YNB, $0.016 \mu \mathrm{M}$ biotin), BMMYA $(10 \mathrm{~g} / \mathrm{L}$ yeast extract, $20 \mathrm{~g} / \mathrm{L}$ peptone, 5g/L methanol, $\mathrm{pH} 6.0100 \mathrm{mM}$ potassium phosphate, 13.4g/L YNB, $0.016 \mu \mathrm{M}$ biotin, $6 \mathrm{~g} / \mathrm{L}$ agar).

\section{Production of proRCL variants by error-prone PCR}

The first two rounds of random mutagenesis of proRCL gene were carried out by error-prone PCR as described elsewhere [43]. A $50 \mu \mathrm{L}$ reaction mixture contained $5 \mu \mathrm{L}$ PCR Gold buffer, $0.7 \mathrm{mM} \mathrm{MnCl} 2,3 \mathrm{mM} \mathrm{MgCl}_{2}, 0.5 \mathrm{mM}$ $\mathrm{dATP} / \mathrm{dGTP}, 2.5 \mathrm{mM} \mathrm{dCTP} / \mathrm{dTTP}, 40 \mathrm{pmol}$ of each primer (BC-F and BC-R), 5 ng of plasmid pPIC9K-proRCL, and $2.5 \mathrm{U}$ of $\mathrm{Taq}$ polymerase. PCR cycle conditions were: initial denaturation for $3 \mathrm{~min}$ at $94^{\circ} \mathrm{C}$; followed by 30 cycles of $30 \mathrm{~s}$ at $94^{\circ} \mathrm{C}, 30 \mathrm{~s}$ of annealing at $55^{\circ} \mathrm{C}$ and $1 \mathrm{~min}$ of extension at $72^{\circ} \mathrm{C}$; and a $10 \mathrm{~min}$ final extension at $72^{\circ} \mathrm{C}$. The template for the second round of errorprone PCR used an equimolar mixture of positive variants from the first generation of random mutagenesis.

\section{Production of proRCL variants by DNA shuffling}

The last two rounds of random mutagenesis of proRCL gene were carried out by DNA shuffling based on the previously methodology reported by Zhao and Arnold [44]. The DNA template was an equimolar mixture of positive variants from the former round. The template was digested with $0.1 \mathrm{U}$ DNase I in $200 \mu \mathrm{L}$ of $50 \mathrm{mM}$ Tris- $\mathrm{HCl} \mathrm{pH} \mathrm{7.4,} 1 \mathrm{mM} \mathrm{MgCl}_{2}$ for $10 \mathrm{~min}$ at $37^{\circ} \mathrm{C}$.
Fragments of $50-100 \mathrm{bp}$ were purified by gel extraction (QIAGEN). Then purified fragments were resuspended in PCR mixture (without primers) containing $5 \mu \mathrm{L}$ PCR Gold buffer, $200 \mu \mathrm{M}$ of each dNTP and $1.25 \mathrm{U}$ of Taq polymerase. PCR cycle conditions were: initial denaturation for $3 \mathrm{~min}$ at $94^{\circ} \mathrm{C}$; followed by 10 cycles of $30 \mathrm{~s}$ at $94^{\circ} \mathrm{C}, 30 \mathrm{~s}$ of annealing at $45^{\circ} \mathrm{C}$ and $1 \mathrm{~min}$ of extension at $72^{\circ} \mathrm{C} ; 10$ cycles with annealing temperatures of $48^{\circ} \mathrm{C}$ and $51^{\circ} \mathrm{C}$, respectively; and a $10 \mathrm{~min}$ final extension at $72^{\circ} \mathrm{C}$. Then, $1-3 \mu \mathrm{L}$ of primerless $\mathrm{PCR}$ product was added to a $50 \mu \mathrm{L}$ PCR mixture with $2 \mu \mathrm{M}$ primers (BCF/BC-R). Other PCR conditions were similar to those described above, and a single product comprising fulllength proRCL was obtained.

\section{Production of his4 3'-end containing fragment (vector fragment $A$ and $D$ )}

Expression vector fragments were prepared by PCR amplification. The plasmid pPIC9K-proRCL was first amplified using flanking primers A-F/A-R or D-F/D-R to produce vector fragment $A$ or $D$ (Figure 1). The PCR was carried out in a final volume of $50 \mu \mathrm{L}$ containing a mixture of $50 \mathrm{ng}$ plasmid pPIC9K-proRCL, $1 \mu \mathrm{M}$ of each primers, $5 \mu \mathrm{L}$ PrimeSTAR DNA polymerase buffer, $100 \mu \mathrm{M}$ of each dNTP and $1.25 \mathrm{U}$ of PrimeSTAR DNA polymerase. PCR cycle conditions were: initial denaturation for $3 \mathrm{~min}$ at $94^{\circ} \mathrm{C}$; followed by 30 cycles of $30 \mathrm{~s}$ at $94^{\circ} \mathrm{C}, 30 \mathrm{~s}$ of annealing at $50^{\circ} \mathrm{C}$ and $2.5 \mathrm{~min}$ or $7.5 \mathrm{~min}$ extension at $72^{\circ} \mathrm{C}$ for fragment $\mathrm{D}$ or $\mathrm{A}$, respectively; and a 10 min final extension at $72^{\circ} \mathrm{C}$.

\section{Library construction}

P. pastoris was transformed with $2 \mu \mathrm{g}$ of fragments $\mathrm{A}, \mathrm{D}$ and $\mathrm{B} / \mathrm{C}$ in a 10:1:1 molar ratio by electroporation according to the protocol reported by $\mathrm{Wu}$ and Letchworth [45]. Briefly, the competent cells, pretreated with $0.1 \mathrm{M}$ lithium acetate and $10 \mathrm{mM}$ dithiothreitol, were transformed with $2 \mu \mathrm{g}$ DNA fragments by electroporation with instrument settings of $1.5 \mathrm{kV}, 25 \mu \mathrm{F}$ and 186 $\Omega$. Transformed yeast colonies appeared in 4-6 days at $30^{\circ} \mathrm{C}$ on $\mathrm{MD}$ plates. The variants were confirmed by DNA sequencing (Sangon Biotech Company).

\section{Overlapping sequence length}

In order to optimise the recombination efficiency, the length of the overlapping sequences between vector and gene fragments was optimized. It was noteworthy that the lipase gene fragment was be produced by normal PCR (called L) instead of ep-PCR. We generated fragment L using $10 \mathrm{bp}, 25 \mathrm{bp}, 40 \mathrm{bp}, 60 \mathrm{bp}, 70 \mathrm{bp}$ and $85 \mathrm{bp}$ of overlapping primers listed in Table 4. These fragments were mixed with fragment $A$ and $D$ in a 10:1:1 molar ratio and electroporated into $P$. pastoris. 


\begin{tabular}{|c|c|}
\hline Primer & Oligonucleotide sequence \\
\hline BC-F & GCTGCTAAAGAAGAAGGGGTATCTCTCGAGAAAAGAGAGGCTGAAGCTTACGTAGAATTCCCTAGG \\
\hline BC-R & GTAAGTGCCCAACTTGAACTGAGGAACAGTCATGTCTAAGGCGAATTAATTCGCGGCCGC \\
\hline$A-F$ & GGCCGCGAATTAATTCGCCTTAGACATG \\
\hline$A-R$ & AGATCTTGATATAAATTTCACGTTTAAAATC \\
\hline D-F & TCGACAATTGGTTTGACTAATTCCATAATCTG \\
\hline D-R & ACCTTTCGTCTTTGGATGTTAGTCT \\
\hline BC-F10 & ATTCCCTAGG \\
\hline BC-R10 & TCGCGGCCGC \\
\hline BC-F25 & TGAAGCTTACGTAGAATTCCCTAGG \\
\hline BC-R25 & CTAAGGCGAATTAATTCGCGGCCGC \\
\hline $\mathrm{BC}-\mathrm{F} 40$ & CGAGAAAAGAGAGGCTGAAGCTTACGTAGAATTCCCTAGG \\
\hline BC-R40 & GAGGAACAGTCATGTCTAAGGCGAATTAATTCGCGGCCGC \\
\hline BC-F55 & GAAGGGGTATCTCTCGAGAAAAGAGAGGCTGAAGCTTACGTAGAATTCCCTAGG \\
\hline BC-R55 & GCCCAACTTGAACTGAGGAACAGTCATGTCTAAGGCGAATTAATTCGCGGCCGC \\
\hline BC-F70 & CATTGCTGCTAAAGAAGAAGGGGTATCTCTCGAGAAAAGAGAGGCTGAAGCTTACGTAGAATTCCCTAGG \\
\hline BC-R70 & CGGTCTTCTCGTAAGTGCCCAACTTGAACTGAGGAACAGTCATGTCTAAGGCGAATTAATTCGCGGCCGC \\
\hline BC-F85 & TACTACTATTGCCAGCATTGCTGCTAAAGAAGAAGGGGTATCTCTCGAGAAAAGAGAGGCTGAAGCTTACGTAGAATTCCCTAGG \\
\hline BC-R85 & AGAATCTAGCAAGACCGGTCTTCTCGTAAGTGCCCAACTTGAACTGAGGAACAGTCATGTCTAAGGCGAATTAATTCGCGGCCGC \\
\hline BC-F65 & CTGCTAAAGAAGAAGGGGTATCTCTCGAGAAAAGAGAGGCTGAAGCTTACGTAGAATTCCCTAGG \\
\hline BC-R65 & TTCTCGTAAGTGCCCAACTTGAACTGAGGAACAGTCATGTCTAAGGCGAATTAATTCGCGGCCGC \\
\hline
\end{tabular}

The number in the name of the primers indicated the length of the overlapping sequences.

\section{Pre-screening}

Colonies from libraries of each generation were replicated with sterile toothpicks from MD plates onto YPD plates (for the storage of variants) and BMMYA plates (for gene expression and screening), simultaneously. The parent strain was used as a positive control. YPD and BMMYA plates were then incubated at $28-30^{\circ} \mathrm{C}$ for $2 \mathrm{~d}$ and $5 \mathrm{~d}$, respectively. Then, BMMYA plates from each ep-PCR and DNA shuffling generation were subjected to heat-treatment at $45^{\circ} \mathrm{C}, 50^{\circ} \mathrm{C}$, $55^{\circ} \mathrm{C}$ and $65^{\circ} \mathrm{C}$, respectively, for $60 \mathrm{~min}$. Screening was performed with $15 \mathrm{~mL}$ of top agar $(5 \mathrm{~g} / \mathrm{L})$ containing $160 \mu \mathrm{L}$ of Fast blue RR (89g/L in dimethyl sulfoxide) and $80 \mu \mathrm{L} \alpha$-naphthyl acetate $(40 \mathrm{~g} / \mathrm{L}$ in dimethyl formamide) [46]. Positive colonies exhibited dark brown coloration within two minutes after pouring the top agar and were further screened using the 96 MTPs screening method.

\section{Screening for evolved variants}

All positive candidates screened from top-agar staining were picked and cultivated in deep-well microtiter plates containing $900 \mu \mathrm{L}$ of BMGY medium, at $28^{\circ} \mathrm{C}, 300 \mathrm{rpm}$ for $16 \mathrm{~h}$ to reach an $O D_{600}$ of 1 . Then, cultures were harvested by centrifugation at $3000 \mathrm{~g}$ at $4^{\circ} \mathrm{C}$ for $10 \mathrm{~min}$ and the cells were suspended in $300 \mu \mathrm{L}$ of BMMY medium for gene expression. The cultures were kept at $28^{\circ} \mathrm{C}, 300 \mathrm{rpm}$ for $84 \mathrm{~h}$ with supply of $100 \mu \mathrm{L}$ fresh BMMY medium and $10 \mathrm{~g} / \mathrm{L}$ methanol every $24 \mathrm{~h}$.

Each culture was centrifuged at $5000 \mathrm{~g}$ at $4^{\circ} \mathrm{C}$ for $10 \mathrm{~min}$. The supernatant was then transferred into $96-$ well microtiter plates for heat-treatment at $60^{\circ} \mathrm{C}$ or $65^{\circ} \mathrm{C}$ for $60 \mathrm{~min}$. Initial and residual lipase activities were measured. All the assays were done in triplicate and significant differences $(\mathrm{p}<0.05)$ were measured. Only variants that showed both higher ratio of residual activity and similar initial activity compared to the parent enzyme were selected.

\section{Enzyme purification}

A single colony from each variant was cultivated in $100 \mathrm{~mL}$ of BMGY medium shaken at $28^{\circ} \mathrm{C}$ and $250 \mathrm{rpm}$ in $500 \mathrm{~mL}$ glass flasks. When cultures reached an $O D_{600}$ of 1 , the cells were centrifuged and resuspended in $25 \mathrm{~mL}$ of BMMY medium to obtain an $O D_{600}$ of 4 and shaken at $28^{\circ} \mathrm{C}$ and $250 \mathrm{rpm}$ in $250 \mathrm{~mL}$ glass flasks for $84 \mathrm{~h}$. The cultures were supplemented with methanol $(5 \mathrm{~g} / \mathrm{L})$ to induce the expression of lipase every $12 \mathrm{~h}$. The culture was then centrifuged and the supernatant was collected for protein purification. 
Cell free medium was concentrated and interchanged with $10 \mathrm{mM}$ Tris- $\mathrm{HCl}$ buffer ( $\mathrm{pH} \mathrm{7.5)} \mathrm{by} \mathrm{ultra} \mathrm{filtration}$ through a $10-\mathrm{kDa}$ membrane (Millipore). The concentrated solution was loaded onto a SP-Sepharose column (AKTA, $1 \mathrm{~cm} \times 20 \mathrm{~cm}$ ) equilibrated with $20 \mathrm{mM}$ Tris$\mathrm{HCl}$ buffer $(\mathrm{pH} 7.5)$ and eluted with $0-0.5 \mathrm{M} \mathrm{NaCl}$ in the same buffer. Fractions containing lipase activity were pooled, concentrated and loaded on a Phenyl-sepharose $6 \mathrm{FF}$ column (AKTA, $1.6 \mathrm{~cm} \times 20 \mathrm{~cm}$ ) equilibrated in $50 \mathrm{mM}$ Tris- $\mathrm{HCl}$ buffer ( $\mathrm{pH} 7.5)$ containing $1.6 \mathrm{M}$ ammonium sulfate. Lipase was then eluted in an ammonium sulfate concentration gradient decreasing from 1.6 to $0 \mathrm{M}$ in $50 \mathrm{mM}$ Tris- $\mathrm{HCl}$ buffer $(\mathrm{pH} 7.5)$ and $4 \mathrm{~mL}$ fractions were collected at a flow rate of $0.8 \mathrm{~mL} / \mathrm{min}$.

\section{Lipase properties}

Lipase activity was measured on emulsified $p$-nitrophenyl palmitate ( $p$ NPP) according to Kordel et al. [47]. Unless stated otherwise, the typical enzymatic reaction was carried out at $40^{\circ} \mathrm{C}, \mathrm{pH} 8.5$. One enzyme unit was defined as the amount of enzyme releasing $1 \mu \mathrm{mol}$ of $p$ nitrophenol per minute under the assay conditions. Optimal temperature $\left(T_{\text {opt }}\right)$ was determined by measuring the enzyme activity at $\mathrm{pH} 8.5$ under various temperatures $\left(20-60^{\circ} \mathrm{C}\right) . T_{\mathrm{m}}$ values were determined as described previously [43]. $10 \mathrm{U}$ purified enzyme solutions were incubated for $30 \mathrm{~min}$ in the temperature range of $20-80^{\circ} \mathrm{C}$, cooled in the ice bath for $20 \mathrm{~min}$ and equilibrated at room temperature for $5 \mathrm{~min}$. Then, residual activity was determined at $40^{\circ} \mathrm{C}$ and expressed as a percentage of the initial activity. The temperature at which $50 \%$ of lipase activity lost was the $T_{\mathrm{m}}$ value. Purified enzymes were incubated at specific temperatures $\left(60^{\circ} \mathrm{C}\right.$ and $\left.65^{\circ} \mathrm{C}\right)$ for half-life $\left(t_{1 / 2}\right)$ determination. $10 \mathrm{U}$ purified enzyme solutions were taken at various time intervals, cooled in the ice bath for $20 \mathrm{~min}$ and equilibrated at room temperature for $5 \mathrm{~min}$. Then, residual activity was determined and the incubation time at which $50 \%$ of lipase activity lost was the $t_{1 / 2}$ value. Inactivation was followed until $>80 \%$ of the activity was lost. The Michaelis-Menten kinetic parameters $k_{\text {cat }}$ and $K_{\mathrm{m}}$ were calculated using $p \mathrm{NPP}$ as substrate. Lineweaver-Burk plots were used to determine $k_{\text {cat }}$ and $K_{\mathrm{m}}$ parameters, assuming that the reactions followed a simple Michaelis-Menten kinetics.

\section{Thermo-mechanism analysis}

A three-dimensional model of $R$. chinensis lipase was built by SWISS-MODEL protein automated modelling program [48] on the basis of crystal structure of ILGY (crystal structure of lipase II from Rhizopus niveus solved with a resolution of $2.20 \AA$ ) [49], which showed the highest homology of $80.38 \%$ to $R$. chinensis lipase.

\section{Abbreviations}

96 MTPs: 96 micro test plates; pNPP: p-nitrophenyl palmitate.

\section{Competing interests}

The authors declare that they have no competing interests.

\section{Authors' contributions}

Yu made substantial contributions to design the experiments and draft the manuscript. Wang carried out this research work, interpreted the data and drafted the manuscript. Zhang carried out the purification experiment. Xu and Xiao revised the manuscript. All authors read and approved the final manuscript.

\section{Acknowledgments}

Financial support from the National Key Basic Research and Development Program of China (973 Program) (No. 2011CB710800), the National High Technology Research and Development Program of China (863 Program) (No. 2012AA022207, 2011AA02A209 and 2011AA02A210), the Fundamental Research Funds for the Central Universities (JUSRP11014), the Programme of Introducing Talents of Discipline to Universities (111 Project) (111-2-06 ), and the Ministry of Education, R.P. China, and from NSFC (20802027) are greatly appreciated.

\section{Author details}

'State Key Laboratory of Food Science and Technology, Jiangnan University, 1800 Lihu Avenue, Wuxi 214122, China. ${ }^{2}$ Key Laboratory of Industrial Biotechnology, Ministry of Education, School of Biotechnology, Jiangnan University, 1800 Lihu Avenue, Wuxi 214122, China. ${ }^{3}$ School of Medicine and Pharmaceutics, Jiangnan University, Wuxi 214122, China. ${ }^{4}$ Center for Advanced Biotechnology and Medicine, Department of Molecular Biology and Biochemistry, Rutgers University, Piscataway, NJ 08854, USA.

Received: 3 May 2012 Accepted: 28 July 2012

Published: 6 August 2012

\section{References}

1. Sharma R, Chisti Y, Banerjee UC: Production, purification, characterization, and applications of lipases. Biotechnol Adv 2001, 19:627-662.

2. Hasan F, Shah AA, Hameed A: Industrial applications of microbial lipases. Enzyme Microb Technol 2006, 39:235-251.

3. Jaeger KE, Eggert T: Lipases for biotechnology. Curr Opin Biotech 2002, 13:390-397.

4. Mukherjee KD: Lipase-catalyzed reactions for modification of fats and other lipids. Biocatal Biotransfor 1990, 3:277-293.

5. Gandhi NN: Applications of lipase. J Am Oil Chem Soc 1997, 74:621-634.

6. Kamiya N, Ogawa T, Nagamune T: Enhancement of apparent thermostability of lipase from Rhizopus sp. by the treatment with a microbial transglutaminase. Biotechnol Lett 2001, 23:1629-1632.

7. Niu W, Li Z, Tan T: Secretion of pro-and mature Rhizopus arrhizus lipases by Pichia pastoris and properties of the proteins. Mol Biotechnol 2006, 32:73-81.

8. Hiol A, Jonzo MD, Rugani N, Druet D, Sarda L, Comeau LC: Purification and characterization of an extracellular lipase from a thermophilic Rhizopus oryzae strain isolated from palm fruit. Enzyme Microb Technol 2000, 26:421-430.

9. Beer HD, McCarthy JEG, Bornscheuer UT, Schmid RD: Cloning, expression, characterization and role of the leader sequence of a lipase from Rhizopus oryzae. Biochimica et Biophysica Acta 1998, 1399:173-180.

10. Yu XW, Wang LL, Xu Y: Rhizopus chinensis lipase: gene cloning, expression in Pichia pastoris and properties. J Mol Catal B: Enzym 2009, 57:304-311.

11. Xu Y, Wang D, Mu XQ, Zhao GA, Zhang KC: Biosynthesis of ethyl esters of short-chain fatty acids using whole-cell lipase from Rhizopus chinensis CCTCC M201021 in non-aqueous phase. J Mol Catal B: Enzym 2002, 18:29-37.

12. Xu Y, Wang $D, M u X Q, N i$ YQ: Efficient esterification of sorbitan oleate by lipase in a solvent-free system. J Am Oil Chem Soc 2003, 80:647-651.

13. Sun SY, Xu Y, Wang D: Purification and biochemical characterization of an intracellular lipase by Rhizopus chinensis under solid-state fermentation and its potential application in the production of eicosapentaenoic acid (EPA) and docosahexaenoic acid (DHA). J Chem Technol Biotechnol 2009, $84: 435-441$ 
14. Sun $S Y, X u Y$, Wang D: Novel minor lipase from Rhizopus chinensis during solid-state fermentation: Biochemical characterization and its esterification potential for ester synthesis. Bioresource Technol 2009, 100:2607-2612.

15. Li Z, Tang X, Huang W, Liu JG, Tilley M, Yao Y: Rheology, microstructure, and baking characteristics of frozen dough containing Rhizopus chinensis lipase and transglutaminase. Cereal Chem 2011, 88:596-601.

16. Hibbert EG, Dalby PA: Directed evolution strategies for improved enzymatic performance. Microb Cell Fact 2005, 4:29-34.

17. Kohno M, Enatsu M, Funatsu J, Yoshiizumi M, Kugimiya W: Improvement of the optimum temperature of lipase activity for Rhizopus niveus by random mutagenesis and its structural interpretation. J Biotechnol 2001, 87:203-210.

18. Di Lorenzo M, Hidalgo A, Haas M, Bornscheuer UT: Heterologous production of functional forms of Rhizopus oryzae lipase in Escherichia coli. Appl Environ Microbiol 2005, 71:8974-8977.

19. Ueda M, Takahashi S, Washida M, Shiraga S, Tanaka A: Expression of Rhizopus oryzae lipase gene in Saccharomyces cerevisiae. J Mol Catal B: Enzym 2002, 17:113-124.

20. Minning S, Serrano A, Ferrer P, Sola C, Schmid RD, Valero F: Optimization of the high-level production of Rhizopus oryzae lipase in Pichia pastoris. J Biotechnol 2001, 86:59-70.

21. Resina D, Serrano A, Valero F, Ferrer P: Expression of a Rhizopus oryzae lipase in Pichia pastoris under control of the nitrogen source-regulated formaldehyde dehydrogenase promoter. J Biotechnol 2004, Xx 109:103-113.

22. Resina D, Bollok M, Khatri N, Valero F, Neubauer $P$, Ferrer $P$ : Transcriptional response of $P$. pastoris in fed-batch cultivations to Rhizopus oryzae lipase production reveals UPR induction. Microb Cell Fact 2007, 6:21-31.

23. Macauley-Patrick S, Fazenda ML, McNeil B, Harvey LM: Heterologous protein production using the Pichia pastoris expression system. Yeast 2005, 22:249-270.

24. Krainer FW, Dietzsch C, Hajek T, Herwig C, Spadiut O, Glieder A: Recombinant protein expression in Pichia pastoris strains with an engineered methanol utilization pathway. Microb Cell Fact 2012, 11:22-35

25. Niu WN, Li ZP, Zhang DW, Yu MR, Tan TW: Improved thermostability and the optimum temperature of Rhizopus arrhizus lipase by directed evolution. J Mol Catal B: Enzym 2006, 43:33-39.

26. Baudin A, Ozier-Kalogeropoulos O, Denouel A, Lacroute F, Cullin C A simple and efficient method for direct gene deletion in Saccharomyces cerevisiae. Nucleic acids Res 1993, 21:3329-3330.

27. Oldenburg KR, Vo KT, Michaelis S, Paddon C: Recombination-mediated PCR-directed plasmid construction in vivo in yeast. Nucleic acids Res 1997, 25:451-452

28. Musidlowska-Persson A, Bornscheuer UT: Recombinant porcine intestinal carboxylesterase: cloning from the pig liver esterase gene by sitedirected mutagenesis, functional expression and characterization. Protein Eng 2003, 16:1139-1145.

29. Cristea M, Engström $\AA$, Su C, Hörnsten L, Oliw EH: Expression of manganese lipoxygenase in Pichia pastoris and site-directed mutagenesis of putative metal ligands. Arch Biochem Biophys 2005, 434:201-211.

30. Liu Z, Pscheidt B, Avi M, Gaisberger R, Hartner FS, Schuster C, Skranc W, Gruber K, Glieder A: Laboratory evolved biocatalysts for stereoselective syntheses of substituted benzaldehyde cyanohydrins. Chem Bio Chem 2008, 9:58-61.

31. Fernández L, Jiao N, Soni P, Gumulya $Y$, de Oliveira LG, Reetz MT: An efficient method for mutant library creation in Pichia pastoris useful in directed evolution. Biocatal Biotransfor 2010, 28:122-129.

32. Bloom JD, Labthavikul ST, Otey CR, Arnold FH: Protein stability promotes evolvability. Proc Natl Acad Sci 2006, 103:5869-5874.

33. Zumárraga M, Bulter T, Shleev S, Polaina J, Martínez-Arias A, Plou FJ, Ballesteros A, Alcalde M: In vitro evolution of a fungal laccase in high concentrations of organic cosolvents. Chem Biol 2007, 14:1052-1064.

34. García-Ruiz E, Maté D, Ballesteros A, Martinez AT, Alcalde M: Evolving thermostability in mutant libraries of ligninolytic oxidoreductases expressed in yeast. Microb Cell Fact 2010, 9:17

35. Eijsink VGH, Bjork A, Gaseidnes S, Sirevag R, Synstad B, Burg B, Vriend G: Rational engineering of enzyme stability. J Biotechnol 2004, 113:105-120.
36. Johannes TW, Woodyer RD, Zhao H: Directed evolution of a thermostable phosphite dehydrogenase for NAD (P) $\mathrm{H}$ regeneration. Appl Environ Microbiol 2005, 71:5728-5734

37. Li W, Zhou X, Lu P: Structural features of thermozymes. Biotechnol Adv 2005, 23:271-281.

38. Törrönen A, Rouvinen J: Structural and functional properties of low molecular weight endo-1, 4- $\beta$-xylanases. J Biotechnol 1997, 57:137-149.

39. Turunen $\mathrm{O}$, Vuorio M, Fenel F, Leisola M: Engineering of multiple arginines into the Ser/Thr surface of Trichoderma reesei endo-1, 4- $\beta$-xylanase II increases the thermotolerance and shifts the $\mathrm{pH}$ optimum towards alkaline $\mathrm{pH}$. Protein Eng 2002, 15:141-145.

40. Martin A, Sieber V, Schmid FX: In-vitro selection of highly stabilized protein variants with optimized surface. J Mol Biol 2001, 309:717-726.

41. Martin A, Kather I, Schmid FX: Origins of the high stability of an in vitroselected cold-shock protein. J Mol Biol 2002, 318:1341-1349.

42. Vieille C, Zeikus GJ: Hyperthermophilic enzymes: sources, uses, and molecular mechanisms for thermostability. Microbiol Mol Biol Rev 2001 65:1-43

43. Zhao H, Arnold FH: Directed evolution converts subtilisin E into a functional equivalent of thermitase. Protein Eng 1999, 12:47-53.

44. Zhao H, Arnold FH: Optimization of DNA shuffling for high fidelity recombination. Nucleic Acids Res 1997, 25:1307-1308.

45. WU SX, Letchworth GJ: High efficiency transformation by electroporation of Pichia pastoris pretreated with lithium acetate and dithiothreitol. Biotechniques 2004, 36:152-154

46. Khalameyzer V, Fischer I, Bornscheuer U, Altenbuchner J: Screening, nucleotide sequence, and biochemical characterization of an esterase from Pseudomonas fluorescens with high activity towards lactones. Appl Environ Microbiol 1999, 65:477-482.

47. Kordel M, Hofmann B, Schomburg D, Schmid RD: Extracellular lipase of Pseudomonas sp. strain ATCC 21808: purification, characterization crystallization, and preliminary X-Ray diffraction data. J Bacteriol 1991, 173:4836-4841.

48. Bordoli L, Schwede T: Automated protein structure modeling with SWISSMODEL workspace and the protein model portal. Methods Mol Biol (Clifton, NJ) 2012, 857:107-136.

49. Kohno M, Funatsu J, Mikami B, Kugimiya W, Matsuo T, Morita Y: The crystal structure of lipase II from Rhizopus niveus at $2.2 \AA$ resolution. J Biochem 1996, 120:505-510.

doi:10.1186/1475-2859-11-102

Cite this article as: Yu et al:: Enhanced thermostability of a Rhizopus chinensis lipase by in vivo recombination in Pichia pastoris. Microbial Cell Factories 2012 11:102

\section{Submit your next manuscript to BioMed Central and take full advantage of:}

- Convenient online submission

- Thorough peer review

- No space constraints or color figure charges

- Immediate publication on acceptance

- Inclusion in PubMed, CAS, Scopus and Google Scholar

- Research which is freely available for redistribution 